\title{
Suspicious breast pseudocalcifications
}

\author{
Nuno André Almeida Costa, ${ }^{1}$ Gisela Rio, ${ }^{2}$ João Garrido Santos ${ }^{1}$
}

Radiology, Instituto Portugues de Oncologia do Porto Francisco Gentil, EPE, Porto, Portugal ${ }^{2}$ Radiology, Hospital de Braga, Braga, Portugal

\section{Correspondence to}

Dr Nuno André Almeida Costa, nunoada@hotmail.com

Accepted 29 August 2018

\section{DESCRIPTION}

We present a follow-up case of an invasive right ductal breast carcinoma in a 72-year-old woman.

A follow-up mammography study (figure 1) performed 1 year after right lumpectomy (wide local excision) shows postsurgical changes in the right breast and reveals 'de novo' coarse/amorphous microcalcifications in the left breast axis. Some of these calcifications show radiolucent centre, and can only be depicted in the craniocaudal mammographic images, raising concern for hypothetic cutaneous location, although presenting suspicious features.

Cancer biomarkers and clinical status were unremarkable.

An ultrasound (US) evaluation was further advised. The patient was told not to apply any cream, lotion or deodorant on the day of the US study. Two weeks later, the patient was referred for

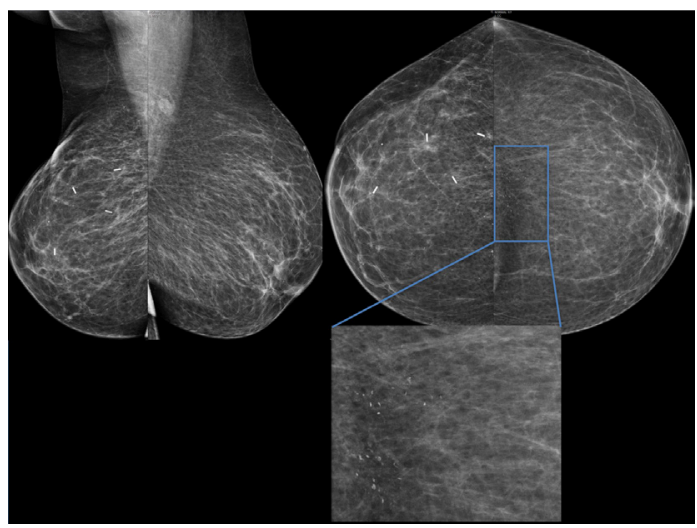

Figure 1 Mammographic images showing postlumpectomy (wide local excision) changes in the right upper outer quadrant and coarse and amorphous calcifications in the left breast. Blue square shows the magnification of the calcifications, revealing some calcifications with radiolucent centre.

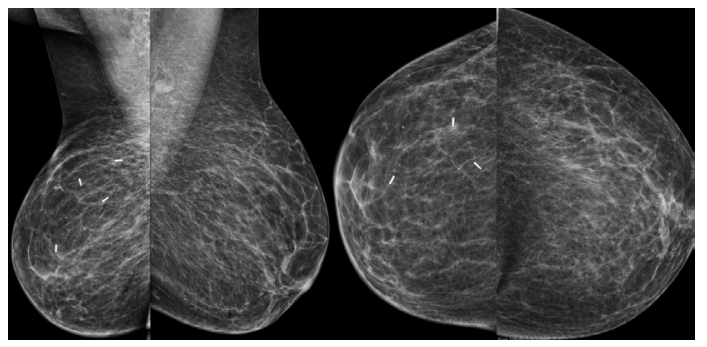

Figure 2 Mammographic images obtained 2 weeks after revealing the total absence of the calcificationspseudocalcifications due to previous application of zincbased ointment on the breast sulcus. the US examination. The evaluation was unremarkable. On the same day, a mammography study was repeated (figure 2) revealing total absence of the calcifications previously seen.

The patient reveals previous use of a zinc-based ointment on the breast sulcus, which she applied on the day of the first mammographic study. Ointment, deodorant and talcum may contain radiopaque components such as zinc, aluminium and magnesium, which may simulate calcifications at mammography. ${ }^{12}$

Artefacts reduce the quality of mammograms and may mimic or obscure abnormalities and cause interpretation errors. ${ }^{3}$

This case highlights the importance of obtaining high-quality mammographic images for accurate diagnosis as mammographic artefacts may obscure the true abnormalities or create pseudolesions.

\section{Learning points}

Ointment, deodorant and talcum may contain radiopaque components such as zinc, aluminium and magnesium, which may simulate calcifications at mammography.

- To prevent these artefacts, technologists should inform the patients, in advance, not to wear powder, deodorant and body cream or ointment prior to the mammographic examination.

- Mammographic artefacts may obscure the true abnormalities or create pseudolesions.

Contributors NAAC, GR and JGS: substantial contributions to the conception or design of the work, or the acquisition, analysis or interpretation of data. NAAC: drafting the work or revising it critically for important intellectual content; final approval of the version published; agreement to be accountable for all aspects of the work in ensuring that questions related to the accuracy or integrity of any part of the work are appropriately investigated and resolved.

Funding The authors have not declared a specific grant for this research from any funding agency in the public, commercial or not-for-profit sectors.

Competing interests None declared.

Patient consent Obtained.

Provenance and peer review Not commissioned; externally peer reviewed.

\section{REFERENCES}

1 Chaloeykitti L, Muttarak M, Ng KH. Artifacts in mammography: ways to identify and overcome them. Singapore Med J 2006;47:634-41.

2 Hogge JP, Palmer CH, Muller CC, et al. Quality assurance in mammography: artifact analysis. Radiographics 1999;19:503-22.

3 Geiser WR, Haygood TM, Santiago L, et al. Challenges in mammography: part 1, artifacts in digital mammography. AJR Am J Roentgenol 2011;197:W1023-W1030 
Copyright 2018 BMJ Publishing Group. All rights reserved. For permission to reuse any of this content visit http://group.bmj.com/group/rights-licensing/permissions.

BMJ Case Report Fellows may re-use this article for personal use and teaching without any further permission.

Become a Fellow of BMJ Case Reports today and you can:

- Submit as many cases as you like

- Enjoy fast sympathetic peer review and rapid publication of accepted articles

Access all the published articles

- Re-use any of the published material for personal use and teaching without further permission

For information on Institutional Fellowships contact consortiasales@bmjgroup.com

Visit casereports.bmj.com for more articles like this and to become a Fellow 